JIPPF, Vol. 1, Edisi 1, Halaman: 44-51

\title{
EFEKTIVITAS MODEL PROBLEM SOLVING BERBANTUAN SELF-DIAGNOSIS SHEET DALAM MEREMEDIASI KESALAHAN MENYELESAIKAN SOAL MATERI ENERGI
}

\author{
${ }^{1 *}$ Oktavianus Liyu, ${ }^{2}$ Haratua Tiur Maria Silitonga, ${ }^{3}$ Erwina Oktavianty \\ 1,2,3Program Studi Pendidikan Fisika FKIP Untan Pontianak \\ Email:oktavianusliyu@gmail.com
}

\section{INFO ARTIKEL}

Diterima 00 Juni 2020

Dipublikasikan 00 Agustus 2020

\begin{abstract}
The purpose of this study was to examine the effectiveness of Problem Solving Model assisted with the self-diagnosis sheet to remediating students' mistake in solving about energy on grade of SMAN 5 Pontianak. The form of research was pre-experimental design with one group pre-test post-test design. The data collection was used in this research was essay tests of five questions. The research sample was chosen using the Intact Group technique. In generaly the percentage of students' mistakes completing questions before remediation is $54.32 \%$, while the percentage of students' mistakes completing questions after remediation is $13.81 \%$. The used of self-diagnosis sheet assisted problem solving models was effective in remediating students' mistakes in solving problems with the effect size of 0.75 categorized as high. This research is expected to be used as an alternative learning activity in class to overcome the mistakes in completing questions experienced by students.
\end{abstract}

Keywords: Energy, Problems Solving Error, Problem Solving Model, Remediation, Self-Diagnosis Sheet

\section{Pendahuluan}

Salah satu karakteristik pembelajaran fisika adalah adanya aktivitas pemecahan masalah (penyelesaikan soal). Hal ini sejalan dengan Heller (dalam Setiani, 2016) yang menyatakan bahwa pemecahan masalah merupakan salah satu alat utama dalam fisika. Aktivitas pemecahan masalah (penyelesaikan soal) mendorong peserta didik berpikir dalam menganalisa masalah, mensintesis dan menerapkan konsep yang sesuai dalam proses pemecahan masalah.

Kompetensi pelajaran fisika menurut Permendikbud No. 21 Tahun 2016 tentang standar isi pendidikan dasar dan menengah ialah peserta didik dapat menganalisis konsep, prinsip, dan hukum-hukum fisika, serta menerapkan metakognisi dalam menjelaskan fenomena alam dan penyelesaian masalah kehidupan (BSNP, 2016). Penyelesaian masalah yang berkaitan dengan konsep-konsep fisika harus berdasarkan pada prinsip-prinsip ilmiah dan etika (Kemdikbud, 2017). Namun, faktanya peserta didik belum mampu menerapkan pengetahuannya dalam menyelesaikan soal-soal fisika dilihat dari hasil belajar peserta didik masih tergolong rendah.

Berdasarkan hasil survey PISA 2015 yang menunjukan bahwa Indonesia berada pada peringkat 62 dari 72 negara yang dievaluasi dengan nilai yang diperoleh pada bidang sains yaitu 403 sedangkan rata-rata OECD adalah 493 (Kemendikbud, 2016). Selain itu, rendahnya hasil belajar peserta didik di Indonesia juga dilihat dari hasil Trends International Mathematics and Science Study (TIMSS). Berdasarkan hasil survey yang dilakukan Trends International Mathhematics and Science Study (TIMSS) pencapaian peserta didik di Indonesia menempati rangking ke 45 dari 48 negara. Dari hasil survey PISA dan TIMSS tersebut menjadi gambaran umum bahwa pencapaian hasil belajar peserta didik di Indonesia masih tergolong rendah.

Selain dari hasil PISA dan hasil TIMSS yang menunjukan hasil belajar yang rendah juga dapat dilihat dari data Puspendik tentang hasil Ujian Nasional (UN) peserta didik untuk SMA yang ada di kota Pontianak. Berdasarkan data Puspendik tentang hasil UN mata pelajaran fisika khususnya SMA Negeri 5 Pontianak dilaporkan hasil UN yaitu: pada tahun pelajaran 2015/2016 hasil UN SMA Negeri 5 Pontianak dikatagorikan "cukup" dengan rata-rata nilai 72,98. Pada tahun pelajaran 2016/2017 hasil UN SMA Negeri 5 Pontianak dikatagorikan "kurang" dengan rata-rata nilai 43,64. Pada tahun pelajaran 2017/2018 hasil UN SMA Negeri 5 Pontianak dikatagorikan " sangat kurang", dengan rata-rata nilai 38,75 (Puspendik, 2018). Jika dilihat dari laporan tersebut tampak bahwa nilai rata-rata ujian nasional mata pelajaran fisika untuk SMA Negeri 5 Pontianak mengalami penurunan. 
Penurunan hasil UN diduga karena kurangnya kemampuan peserta didik dalam memecahan masalah khususnya menyelesaikan soal sehingga meyebabkan kesalahan. Kesalahan dalam menyelesaikan soal yang sering terjadi menurut Sari (2013) yaitu kesalahan terjemahan, kesalahan strategi, kesalahan konsep, dan kesalahan hitung. Menurut lemer yang dikutip oleh abdurahman (2012) kekekeliruan umum dalam menyelesaikan soal adalah kurang pemahaman tentang simbol, nilai, tempat, perhitungan, penggunaan proses yang keliru, dan tulisan yang tidar terbaca.

Kemampuan pemecahan masalah merupakan salah satu keterampilan berpikir yang penting untuk dikuasai di abad ke-21. Menurut Chrisnawati sebagaimana yang dikutip oleh Hidayat (2017) kemampuan pemecahan masalah adalah kemampuan yang penting dimiliki oleh peserta didik karena kemampuan pemecahan masalah dapat mendorong peserta didik untuk menyusun sendiri teorinya (their own theories), mengujinya, menguji teori temannya, membuangnya jika teori tersebut tidak konsisten dan mencoba yang lainnya. Berdasarkan pendapat tersebut, keterampilan pemecahan masalah dapat diartikan sebagai suatu usaha dalam menyelesaikan masalah dengan memanfaatkan ilmu pengetahuan yang dimiliknya hingga penemuan solusi dari suatu masalah.

Mencermati pentingnya aktivitas pemecahan masalah dalam pembelajaran fisika, maka model pembelajaran berbasis masalah dapat diterapkan untuk mereduksi kesalahan peserta didik dalam menyelesaikan soal. Pembelajaran berbasis masalah tidak mengharapkan peserta didik hanya sekedar mendengarkan, mencatat, kemudian menghafal materi yang dicatat, akan tetapi melalui pembelajaran berbasis masalah peserta didik aktif berpikir, berkomunikasi, mencari dan mengolah data dan akhirnya menyimpulkan (Kasmad, 2012: 107). Menurut Gagne, keterampilan intelektual tingkat tinggi dapat dikembangkan melalui aktivitas pemecahan masalah. Oleh karena itu, keterampilan pemecahan masalah merupakan hal yang penting untuk diasah.

Penyebab kesalahan peserta didik dalam menyelesaikan soal harus segera mendapat pemecahan yang tuntas agar tidak mempengaruhi hasil belajar peserta didik di tingkat selanjutnya. Untuk mengatasi hal tersebut, maka diperlukan adanya kegiatan remediasi. Remediasi merupakan usaha pengulangan pembelajaran dengan cara yang lain setelah dilakukan diagnosa masalah belajar (Depdiknas, 2008). Tujuan dilakukan remediasi yaitu untuk membenahi masalah belajar peserta didik sehingga setelah diberikan remediasi, diharapkan hasil belajar serta pemahaman konsep yang dicapai oleh peserta didik menjadi lebih baik.

Salah satu kegiatan remediasi yang sesuai menurut peneliti yaitu dengan menggunakan model Problem Solving. Model Problem Solving merupakan salah satu model pembelajaran pemecahan masalah yang dapat mendorong peserta didik untuk berpikir secara sistematis. Pembelajaran menggunan model problem solving menjadi sangat penting, karena dalam belajar, peserta didik cepat lupa jika hanya dijelaskan secara lisan, ingatan peserta didik akan lebih lama jika diberikan contoh, dan memahami jika diberikan kesempatan mencoba menyelesaikan masalah (Dennys, 2013).

Model pembelajaran Problem Solving menurut Logical Problem Solving dalam pembelajaran fisika memiliki lima langkah pembelajaran. Langkah-langkah model Problem Solving yang dikembangkan di Universitas Minnesota untuk pembelajaran fisika terdiri dari lima langkah yaitu, memfokuskan permasalahan (comprehend the problem), menjabarkan aspek fisiknya (represent the problem in formal term), rencana pemecahan (plan a solution), menjalankan rencana (execute the plan), mengevaluasi jawaban (evaluate the answer) (Warimun, 2012).

Pada langkah terakhir problem solving yaitu mengevaluasi jawaban, pada langkah ini peserta didik mengecek kembali kelengkapan jawaban berupa satuan, tanda, dan mengevaluasi hasil yang diperoleh untuk disesuaikan dengan konsep yang digunakan. Selain itu, peserta didik dapat meninjau kembali kesalahan-kesalahan dan kekeliruannya dalam menjawab soal. Kegiatan meninjau kembali kesalahan-kesalahan didalam diri peserta didik dinamakan dengan self-diagnosis.

Self-diagnosis merupakan bagian dari proses berpikir refleksi. Safadi (2016) dalam penelitiannya menemukan bahwa aktivitas self-diagnosis efektif dalam meningkatkan pemahaman konsep dan prestasi belajar peserta didik. Diagnosis diri (self-diagnosis) merupakan proses untuk mendiagnosa atau mengidentifikasi kondisi dalam diri terutama kesalahan yang telah dilakukan dalam mengerjakan soal (Puti, 2016). Untuk membantu peserta didik mendiagnosa kondisi dalam dirinya dapat dilakukan dengan memberikan item pernyataan dalam bentuk lembaran yang memuat kunci jawaban dimana peserta didik mendiagnosa kondisi dalam diri terutama kesalahan dalam menyesaikan soal berdasarkan kunci jawaban yang diberikan yang kemudian dikenal dengan self-diagnosis sheet.

Dari uraian diatas, maka dilakuan penelitian menggunakan model Problem Solving berbantuan self-diagnosis sheet untuk meremediasi kesalahan peserta didik dalam menyelesaikan soal pada materi energi di SMA Negeri 5 Pontianak. 


\section{Metode Penelitian}

Metode penelitian yang digunakan pada penelitian ini adalah Pre-experimental design dengan rancangan one-group pretest-postest design. Menurut Sugiyono (2016: 109) bentuk penelitian dikatakan pre-experimental design karena terdapat variabel luar yang ikut berpengaruh terhadap terbentuknya variabel terikat. Bentuk penelitian ini dipilih karena menggunakan satu kelompok subjek. Walaupun satu kelompok namun dengan adanya tes awal dan tes akhir maka prinsip perbandingan keadaan sebelum dan sesudah dengan pemberian perlakuan di dalam eksperimen terpenuhi. Bentuk penelitian ini ditunjukkan pada Gambar 3.1.

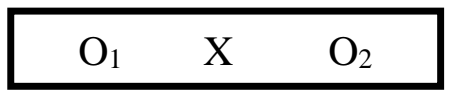

Gambar 3.1 Penelitian Eksperimen One Group Pretes-Posttest Design

Populasi dalam penelitian ini adalah peserta didik kelas X MIPA SMA Negeri 5 Pontianak. Pengambilan sampel dilakukan dengan intact group (kelompok utuh) dan dipilih berdasarkan rekomendasi dari guru mata pelajaran fisika. Berdasarkan rekomendasi dari guru fisika SMA Negeri 5 Pontianak, kelas X MIPA 2 terpilih sebagai sampel yang berjumlah 35 orang.

Teknik pengumpulan data yang digunakan dalam penelitian ini adalah teknik tes (soal). Sugiyono (2016: 308) menyatakan bahwa teknik pengumpul data merupakan langkah yang paling utama dalam penelitian, karena tujuan utama dari penelitian adalah mendapatkan data.

Alat pengumpul data yang digunakan pada penelitian ini berupa soal tes awal (pre-test) dan tes akhir (posttest) berbentuk essay (uraian) berjumlah 5 soal. Soal pretest dan posttest yang dalam penelitian ini divalidasi oleh 2 orang dosen pendidikan fisika FKIP Untan dan satu orang guru SMA Negri 8 Pontianak dengan hasil validasi yang diperoleh sebesar 4,304 (valid). Berdasarkan hasil uji coba soal di SMA Negeri 8 Pontianak didapatkan tingkat reliabilitas soal sebesar 0,502 yang tergolong sedang. Prosedur dalam penelitian ini terdiri dari 3 tahap, yaitu : 1) Tahap persiapan, 2) Tahap pelaksanaan, 3) Tahap akhir.

\section{Tahap Persiapan}

Langkah-langkah yang dilakukan pada tahap persiapan antara lain : (1) melakukan studi literatur; (2) merumuskan masalah; (3) menyiapkan instrumen penelitian berupa kisi-kisi soal, soal pretest dan posttest; (4) melakuankan validasi instrumen penelitian; (5) merevisi instrumen penelitian (6) Melakukan uji coba soal; (7) menganalisis hasi uji coba soal (8) menentukan waktu penelitian.

\section{Tahap Pelaksanaan}

Langkah-langkah yang dilakukan pada tahap pelaksanaan antara lain : (1) memberikan pretest; (2) mengoreksi jawaban peserta didik; (3) memberikan perlakuan berupa kegiatan remediasi menggunakan model Problem Solving berbantun self-diagnosis sheet; (4) memberikan posttest; (5) menganalisis data hasil post-test.

\section{Tahap Akhir}

Langkah-langkah yang dilakukan pada tahap akhir antara lain : (1) Menganalisis data dan membahas hasil penelitian; (2) Membuat kesimpulan; (3) Menyusun laporan penelitian.

\section{Hasil dan Pembahasan}

Penelitian ini merupakan penelitian ekperimen bertujuan untuk menemukan keefektifan model Problem Solving berbantuan self-diagnosis sheet dalam meremediasi kesalahan peserta didik menyelesaikan soal. Model problem solving yang digunakan adalah model problem solving yang dikembangkan oleh Swistoro (2012) terdiri dari lima langkah yaitu: comprehend the problem, represent the problem in formal term, plan a solution, execute the plan, dan evaluate the answer. Kategori kesalahan ditemukan dari analisis jawaban peserta didik dalam menyelesaikan soal sebelum dan sesudah remediasi. Self-diagnosis sheet yang digunakan merupakan suatu lembar koreksian pribadi peserta didik yang di dalamnya memuat kunci jawaban. Peserta didik mengevaluasi dirinya serta menuliskan penyebab kesalahannya pada lembaran self-diagnosis sheet yang diberikan.

Data penelitian yang diperoleh berupa frekuensi kesalahan peserta didik menyelesaikan soal pada pretest dan posttest dengan kesalahan yang diteliti yaitu kesalalahan gambar (KG), kesalahan data (kesalahan menuliskan yang 
diketahui dan ditanya) (KD), kesalahan satuan (KS), kesalahan konsep (KK), kesalahan rumus (KR), dan kesalahan hitung $(\mathrm{KH})$.

Jumlah kesalahan untuk kategori kesalahan gambar sebanyak 5 kesalahan, kesalahan data sebanyak 27 kesalahan, kesalahan satuan sebanyak 30 kesalahan, kesalahan konsep sebanyak 5 kesalahan, kesalahan rumus sebanyak 14 kesalahan, dan kesalahan perhitungan sebanyak 10 kesalahan. Jumlah kesalahan total dari lima soal tersebut berjumlah 91 kesalahan. Persentase kesalahan peserta didik menyelesaikan soal sebelum dan sesudah remediasi seperti pada tabel 1 berikut.

Tabel 1. Persentase Kesalahan Peserta Didik Menyelesaikan Soal Sebelum Dan Sesudah Diberikan Remediasi

\begin{tabular}{ccccc}
\hline Jenis Kesalahan & $\mathrm{f}_{\text {sebelum }}$ & $\% \mathrm{f}_{\text {sebelum }}$ & $\mathrm{f}_{\text {sesudah }}$ & $\%_{\text {sesudah }}$ \\
\hline Kesalahan Gambar & 107 & $61,14 \%$ & 15 & $8,57 \%$ \\
\hline Kesalahan Data & 262 & $27,72 \%$ & 116 & $12,28 \%$ \\
\hline Kesalahan Satuan & 543 & $51,71 \%$ & 207 & $19,71 \%$ \\
\hline Kesalahan Konsep & 175 & $100 \%$ & 22 & $12,57 \%$ \\
\hline Kesalahan Rumus & 368 & $75,10 \%$ & 46 & $9,39 \%$ \\
\hline Kesalahan Hitung & 275 & $78,57 \%$ & 34 & $9,71 \%$ \\
\hline Jumlah & 1730 & $54,32 \%$ & 440 & $13,81 \%$ \\
\hline
\end{tabular}

$\mathrm{f}_{\text {sebelum }}=$ Frekuensi kesalahan sebelum remediasi

$\mathrm{f}_{\text {sesudah }}=$ Frekuensi kesalahan sesudah remediasi

Berdasarkan hasil analisis data pada tabel 1, persentase kesalahan gambar (KG) sebelum remediasi sebesar $61,14 \%$. Pada situasi awal, peserta didik telah mampu mengambarkan situasi soal namun masih kurang tepat. Berdasarkan hasil self-diagnosis sheet peserta didik didapatkan informasi bahwa peserta didik tidak dapat mempresentsikan soal kedalam bentuk lain khususnya gambar. Kesalahan ini disebabkan karena kurangnya pemahaman peserta didik terhadap maksud soal seperti sulitnya dalam menentukan titik acuan benda, akhirnya gambar yang dibuat tidak sesuai dengan representasi gambar yang benar. Ketika diminta untuk mengambarkan keadaan soal, peserta didik kesulitan karena tidak terbiasa untuk mempresentasikan soal tersebut kedalam bentuk gambar. Dalam mengerjakan soal, peserta didik langsung pada inti pertanyaan tanpa mengambarkan situasi soal terlebih dahulu.

Berdasarkan hasil analisis data pada tabel 1, persentase kesalahan data (KD) sebelum remediasi sebesar 27,72 $\%$. Pada situasi awal, peserta didik telah mampu mengidentifikasi data yang diketahui dan ditanyakan karena hal ini sudah umum dilakukan oleh peserta didik dalam mengerjakan soal. Namun masih ada beberapa yang belum lengkap dalam menuliskan data. Berdasarkan hasil self-diagnosis sheet didapatkan informasi tentang penyebab kesalahan yaitu karena ketidaktahuan peserta didik terhadap simbol-simbol dari besaran pada soal yang membuat mereka tidak menuliskannya. Kesalahan peserta didik untuk kategori kesalahan data umumnya disebabkan karena peserta didik yang kurang teliti yang menyebabkan data tersebut terlewatkan dan tidak dituliskan. Hal ini sesuai dengan hasil temuan Hastuti (2011), Penyebab kesalahan adalah peserta didik yang kurang teliti dalam membaca soal.

Berdasarkan hasil analisis data pada tabel 1, persentase kesalahan satuan (KS) sebelum remediasi sebesar 51,71 \%. Pada situasi awal, peserta didik telah mampu memberikan satuan pada setiap besaran namun ada beberapa yang kurang tepat dalam memberikan satuan. Dalam fisika, satuan merupakan suatu yang sangat penting karena satuan menjadi ukuran dari suatu besaran. Berdasarkan hasil self-diagnosis sheet peserta didik didapatkan informasi bahwa peserta didik tidak dapat menentukan satuan dari beberapa besaran dengan benar. Kesalahan ini umumnya dikarenakan kebiasaan peserta didik menghafalkan satuan, yang menyebabkan mereka lupa dengan beberapa satuan khususnya satuan pada materi energi. Hal ini sesuai dengan hasil temuan Hastuti (2011) bahwa penyebab kesalahan satuan karena kebiasaan peserta didik dalam menghafalkan satuan, serta tidak mencantumkan satuan dalam perhitungan.

Dalam menyelesaikan soal fisika, kemampuan mengidentifikasi konsep-konsep yang digunakan menjadi sangat penting. Konsep memungkin untuk menemukan rumus yang tepat dalam mengerjakan soal. Persentase kesalahan konsep paling besar dibandingkan dengan kategori kesalahan yang lain. Persentase kesalahan konsep (KK) sebelum remediasi yaitu sebesar $100 \%$. Artinya, semua peserta didik salah dalam menentukan konsep yang tepat. Dari hasil self-diagnosis sheet peserta didik didapatkan informasi bahwa peserta tidak dapat menentukan konsep fisika yang digunakan pada soal dengan benar. Hal ini karena kurangnya pemahaman peserta didik terhadap konsep sehingga menyebabkan mereka miskonsepsi ketika diminta untuk mengidentifikasi konsep pada 
soal. Peserta didik beranggapan bahwa soal-soal hanya berbentuk hitungan saja karena sebelumnya ketika mengerjakan soal peserta didik tidak terbiasa diminta mengidentifikasi konsep yang terdapat pada soal. Hal ini yang menyebabkan peserta didik mengabaikan untuk mempelajari konsep-konsep fisika. Padahal, kemampuan mengidentifikasi prinsip fisika yang terdapat di dalam soal merupakan salah satu komponen penting dalam memecahkan masalah (Shih \& Singh, 2013).

Jika dilihat pada tabel 1, persentase kesalahan rumus (KR) sebelum remediasi sebesar 75,10\%. Dari hasil ini tampak bahwa kesalahan rumus merupakan suatu kesalahan yang banyak terjadi dalam proses penyelesaian soal. Dari hasil self-diagnosis sheet peserta didik didapatkan bahwa kemampuan peserta didik dalam menentukan rumus yang tepat untuk menyelesaikan soal masih sangat kurang. Sempitnya wawasan terhadap konsep-konsep fisika dan kurangnya kemampuan peserta didik dalam materi apresepsi menyebabkan peserta didik sulit dalam merecanakan solusi (Komariah, 2011). Kesalahan peserta didik dalam menentukan rumus terjadi karena kebiasaan peserta didik dalam menghafalkan rumus yang menyebabkan mereka lupa dalam jangka waktu yang cukup lama.

Dalam fisika tidak hanya sebatas sampai pada penentuan rumus saja tetapi peserta didik juga diharapkan dapat melakukan perhitungan matematis untuk memperoleh jawaban akhir sesuai dengan rumus atau solusi yang sudah ditentukan. Kesalahan hitungan $(\mathrm{KH})$ merupakan kesalahan kedua yang paling banyak dilakukan setelah kesalahan konsep. Persentase kesalahan perhitungan matematis pada keadaan awal sebelum remediasi sebesar $78,29 \%$. Dari hasil self-diagnosis sheet peserta didik ditemukan penyebab kesalahan peserta didik yaitu karena kurang teliti dalam memasukan data pada persamaan matematis sehingga jawabannya salah. Selain itu ditemukan juga beberapa peserta didik yang masih kurang paham dengan operasi perhitungan matematis seperti perpangkatan, pengurangan, penjumlahan dan perkalian menyebabkan jawaban yang didapatkan masih kurang tepat. Menurut Hastuti (2011), kesalahan perhitungan terjadi karena kurangnya pemahaman konsep peserta didik dalam melakuakan operasi hitung. Secara keseluruhan, persentase kesalahan peserta didik dalam menyelesaikan soal pada pretest sebesar 54,29 \%. Pada keadaan awal banyak peserta didik keliru dalam memahami soal baik dalam mepresentasikan soal kedalam bentuk gambar, menentukan satuan, menganalisis konsep, memilih rumus yang tepat serta melakukan perhitungan matematis. hal ini yang menyebabkan persentase jumlah kesalahan yang besar. Kemudian ketika posttest, jumlah kesalahan peserta didik menurun. Secara keseluruhan, persentase penurunan kesalahan peserta didik menyelesaikan soal sebesar 13,81\%. Penurunan jumlah kesalahan peserta didik ini terjadi setelah diberikan remediasi menggunakan model problem solving berbantuan self-diagnosis sheet.

Untuk mengetahui efektivitas remediasi menggunakan model problem solving berbantuan self-diagnosis sheet dapat dilihat menggunakan rumus:

$$
\Delta S=\frac{S_{0}-S_{1}}{S_{0}}
$$

Adapun hasil perhitungan efektivitas remediasi seperti tabel 2 berikut ini.

Tabel 2. Perhitungan Tingkat Efektivitas Remediasi

\begin{tabular}{ccccc}
\hline Jenis Kesalahan & $S_{0}$ & $S_{1}$ & $\Delta S$ & Kategori \\
\hline Kesalahan Gambar & 107 & 15 & 0,86 & Tinggi \\
\hline Kesalahan Data & 262 & 116 & 0,56 & Sedang \\
\hline Kesalahan Satuan & 543 & 207 & 0,62 & Tinggi \\
\hline Kesalahan Konsep & 175 & 22 & 0,88 & Tinggi \\
\hline Kesalahan Rumus & 368 & 46 & 0,88 & Tinggi \\
\hline Kesalahan Hitung & 275 & 34 & 0,65 & Tinggi \\
\hline Jumlah & 1730 & 440 & 0,75 & Tinggi \\
\hline
\end{tabular}

Berdasarkan tabel 2 dapat diketahui tingkat efektivitas kesalahan sebelum dan sesudah diberikan remediasi. Tingkat efektivitas masing-masing kesalahan yang diukur yaitu, kesalahan gambar sebesar 0,86 (tinggi), kesalahan data sebesar 0,56 (sedang), kesalahan satuan sebesar 0,62 (tinggi), kesalahan konsep sebesar 0,88 (tinggi), kesalahan rumus sebesar 0,88 (tinggi), dan kesalahan hitung sebesar 0,65 (tinggi). secara umum tingkat efektivitas kesalahan sebelum dan sesudah remediasi secara umum sebesar 0,75 (tinggi). Hal ini berarti terjadi penurunan kesalahan peserta didik menyelesaikan soal antara sebelum dan sesudah remediasi.

Penggunaan model problem solving dapat menurunkan kesalahan peserta didik karena dengan model problem solving peserta didik dilatih terampil memecahkan masalah. Di dalam model problem solving peserta didik diajarkan menyelesaikan soal secara sistematis mulai dari transformasi soal, penentuan satuan yang tepat, 
indentifikasi konsep yang digunakan, operasi hitung hingga pengecekan dan intepretasi hasil. Pembelajaran dengan model problem solving mengarahkan peserta didik belajar tidak sebatas hanya berhitung tetapi memungkinkan peserta didik dapat menganalisis konsep yang digunakan dalam pemecahan masalahan. Hal ini sesuai dengan Suparno (2013: 102) yang menyatakan bahwa problem solving merupakan salah satu model pembelajaran fisika yang dapat membantu perubahan konsep peserta didik, terutama perubahan konsep fisika yang kurang benar ke yang lebih benar.

Berdasarkan hasil yang didapatkan, diketahui bahwa kemampuan peserta didik sebelum dan setelah diberikan remediasi berbeda. Ini berarti bahwa kesalahan peserta didik sebelum remediasi dapat diperbaiki dengan pemberian remediasi mengunakan model problem solving. Hal ini sesuai dengan hasil temuan Caliskan, et al. (2010) yaitu peningkatan kemampuan penyelesaian soal pada peserta didik lebih besar terjadi pada kelas yang diajarkan dengan strategi pemecahan masalah dibandingkan dengan kelas yang tidak diajarkan strategi pemecahan masalah. Peningkatan kemampuan peserta didik menyelesaikan soal selain karena pembelajaran menggunakan model problem solving juga disebabkan karena adanya bantuan self-diagnosis sheet yang diberikan kepada peserta didik. Self-diagnosis sheet yang diberikan berfungsi untuk mengali informasi awal mengenai penyebab kesalahan peserta didik menyelesaikan soal sehingga remediasi yang diberikan menjadi lebih terarah berdasarkan hasil diagnosis diri peserta didik.

Pembelajaran dengan model problem solving efektif untuk meremediasi kesalahan peserta didik menyelesaiakn soal pada materi energi dengan tingkat efektivitas 0,75 kategori (tinggi) sesuai dengan barometer Hattie. Hal ini sesuai dengan hasil temuan Fitriyatun (2013), bahwa pembelajaran dengan model problem solving lebih efektif dari pada hasil belajar peserta didik yang menggunakan model konvensional yang dilihat dari perbedaan rata-rata hasil belajar. Model problem solving memuat suatu langkah-langkah pembelajaran yang dapat memacu peserta didik untuk berpikir kritis hingga mencari solusi terhadap masalah yang diberikan.

Efektivitas penggunaan model problem solving dalam penelitian ini juga dipengaruhi oleh pemberian selfdiagnosis sheet setelah menyelesaikan soal. Self-diagnosis efektif membantu peserta didik menyadari kesalahankesalahannya dalam menyelesaikan soal hingga menuliskan kesalahannya dalam suatu lembaran yang telah disediakan sebagai evalusi terhadap dirinya sendiri. Hal ini juga sama dengan temuan Safadi (2016) bahwa aktivitas self-diagnosis efektif dalam meningkatkan pemahaman konsep dan prestasi belajar peserta didik. Self-diagnosis sheet yang diberikan membantu peserta didik dalam memahami soal hingga menyelesaikannya langkah demi langkah.

\section{Kesimpulan}

Berdasarkan hasil penelitian, maka dapat disimpulkan bahwa penggunakan model Problem Solving berbantuan Self-Diagnosis Sheet efektif untuk meremediasi kesalahan peserta didik menyelesaikan soal pada materi energi di SMA Negeri 5 Pontianak. Secara khusus dalam penelitian ini dapat disimpulkan bahwa (1) Persentase kesalahan kategori kesalahan gambar sebelum remediasi 61,14\% dan sesudah remediasi 8,57\%, kesalahan data sebelum remediasi (kesalahan variabel yang diketahui dan ditanya) 27,72\% dan sesudah remediasi 12,28\%, kesalahan satuan sebelum remediasi $51,71 \%$ dan sesudah remediasi $19,28 \%$, kesalahan konsep sebelum remediasi 100\% dan sesudah remediasi $12,57 \%$, kesalahan rumus sebelum remediasi $75,10 \%$ dan sesudah remediasi 9,39\%, dan kesalahan perhitungan matematis sebelum remediasi $78,57 \%$ dan sesudah remediasi 9,71\%. (2) Penggunaan model problem solving berbantuan self-diagnosis sheet efektif dalam meremediasi kesalahan peserta didik menyelesaikan soal materi dengan tingkat efektivitas sebesar 0,75 tergolong tinggi. Penelitian selanjutnya diharapkan untuk melakukan penelitian mengunakan kelas pembanding sehingga dapat diketahui pengaruh efektivitas penggunaan self-diagnosis sheet dalam pembelajaran. (2) Berdasarkan temuan ini maka direkomendasikan upaya penelitian selanjutnya untuk mengembangkan self-diagnosis sheet yang dapat digunakan untuk mengetahui pemahaman materi setiap selesai pembelajaran tidak hanya ketika penyelesaian soal saja sehingga kesulitan peserta didik setiap pertemuan dapat diidentifikasi.

\section{Referensi}

Abdurrahman, Mulyono. (2012). Anak Berkesulitan Belajar. Jakarta: Rineka Cipta

BSNP. 2016. Standar Isi Pendidikan Dasar dan Menengah. (online). (http://bsnp-indonesia.org/standar-isi/ diakses 10 Maret 2018). 
Caliskan, et al. 2010. Effect of the problem solving strategies instruction on the students' physics problem solving performances and strategy usage. Procedia Social and Behavioral Sciences.11 Januari 2010, Izmir, Turkey. Hal. 2239-2243.

Dennys, Grace H \& Sahyar. 2013. Efek Model Pembelajaran Problem Solving dan Motivasi Terhadap Hasil Belajar Fisika Siswa SMA. Jurnal Pendidikan Fisika, Vol 2(2).

Depdiknas. 2008. Panduan Penyelenggaraan Pembelajaran Remedial. Direktorat Pembinaan Sekolah Menengah Atas. Jakarta: Dikmenjur - Diknas.

Hastuti, I. Surantoro, \& D.W. Rahardjo. 2011. Analisis Kesalahan Dalam Menyelesaikan Soal Materi Pokok Kalor Pada Siswa Kelas X SMA. Jurnal Materi dan Pembelajaran Fisika. 1-11

Hidayat Syarif R. 2017. Pengenbangan Instrumen Tes Keterampilan Pemecahan Masalah Pada Materi Getaran, Gelombang Dan Bunyi. Jurnal Penelitian Dan Pengembangan Pendidikan Fisika. Vol 3 No 2.

Kasmad, M \& Pratomo, S. 2012. Model Pembelajaran Berbasis Paikem. Tangerang: PT Pustaka Mandiri.

Kemendikbud. 2016. Peringkat dan Capaian PISA Indonesia. (Online). (https://www.kemendikbud.go.id, diakses tanggal 2 Febuari 2019).

Kemdikbud. 2017. Model Silabus Mata Pelajaran Sekolah Menengah Atas/Madrasah Aliyah (SMA/MA). Jakarta: Kementerian Pendidikan dan Kebudayaan.

Komariah, K. 2011. Penerapan Metode Pembelajaran Problem Solving Model Polya untuk Meningkatkan Kemampuan Memecahkan Masalah Bagi Siswa Kelas IX J di SMPN 3 Cimahi. Prosiding Seminar Nasional Penelitian. Yogyakarta, Indonesia. Hal. 181-188.

Nasihan, Fitriyatun. 2014. Pengembangan Modul Dengan Problem Model Solving Berbantuan LKS Dan Puzzquare Untuk Meningkatkan Prestasi Belajar Pada Materi Segiempat SMP. FPMIPA Universitas PGRI Semarang.

Puspendik. 2018. Laporan Hasil Ujian Nasional SMA/MA. (Online). (http://puspendik.kemendikbud.go.id./hasil-un/, diakses tanggal 13 Maret 2019).

Putri. 2016. Analisis Kesalahan Dalam Menyelesaikan Soal Penerapan Fisika Dengan Menggunakan Lembar SelfDiagnosis Pada Mahasiswa Pendidikan Fisika FKIP Universitas Sriwijaya. Jurnal Inovasi dan Pembelajaran Fisika. Palembang: Universitas Sriwijaya.

Safadi, Rafi'. 2016. Self-Diagnosis as A Tool for Supporting Students' Conceptual Understanding and Achievements in Physics: the Case of $8^{\text {th }}$-graders Studying Force and Motion. IOP Publishing Ltd Physics Education.52(1).

Sari, D.M., Surantoro, \& E.Y Ekawati. (2013). Analisis Kesalahan Dalam Menyelesaikan Soal Materi Termodinamika Pada Siswa SMA. Jurnal Materi Dan Pembelajaran Fisika (JMPF). 3(1): 5-8

Setiyani, Feri. 2016. Kemampuan Siswa Dalam Memecahkan Masalah Fisika Pada Berbagai Bentuk Representasi Soal. Skripsi. Universitas Negeri Semarang.

Shih, Y., \& Singh, C. 2013. Using an isomorphic problem pair to learn introductory physics: Transferring from a twostep problem to a three step problem. Physical Review Special Topics - Physics Education Research. 9(2): 1-21.

Suparno, P. 2013. Miskonsepsi \& Perubahan Konsep Dalam Pendidikan fisika. Jakarta: PT Grasindo.

Swistoro, E.W. 2012. Penerapan Model Pembelajaran Problem Solving Fisika Pada Pembelajaran Topik Optika Pada Mahasisiwa Pendidikan Fisika. Jurnal Exacta, Vol X No. 2 